\begin{tabular}{ccccc}
$\mathbf{A}$ & $\mathbf{T}$ & $\mathbf{C}$ & $\mathbf{E}$ & $\mathbf{S}$ \\
\hline & \\
& \\
ROCZNIKI TEOLOGICZNE \\
Volume 65, issue 7 - 2018 \\
E n g 1 i s h v e r s i o n \\
DOI: http://dx.doi.org/10.18290/rt.2018.65.7-1en
\end{tabular}

REV. MAREK JAGODZIŃSKI

\title{
CONSEQUENCES OF CONTEMPORARY CHANGES FOR THEOLOGY AND CHURCH
}

\begin{abstract}
A bstract. The culture of transmodernity is accompanied by a number of changes concerning religion. The secularization theory has ended in failure; the role of spirituality and religion is emphasized. Changes occasionally provoke the thesis that Protestantization and Pentecostalization of Christianity is taking place, leading to fragmentation and decomposition. This is accompanied by a tendency to decentralize the Catholic Church. This poses challenges to theological hermeneutics regarding the reception of Vatican II and the reading of the signs of the times; this also requires the Church to take an appropriate spiritual attitude and define the vision of the future.
\end{abstract}

Key words: transmodernism; secularization; hermeneutics; Protestantization; Pentecostalization; decentralization.

The world we live in is changing rapidly; challenges to and prospects for Christian faith change together with it. In the present century, Catholicism has been undergoing a profound metamorphosis, which manifests itself, for example, in the emergence of evangelical Catholicism. ${ }^{1}$ Fairly recently, Rev.

Rev. Prof. MAREK JAGODZIŃSKi, PhD, DSC - priest of the Diocese of Radom, dogmatic theologian, employed in the Department of Orthodox Theology at the Ecumenical Institute of the John Paul II Catholic University of Lublin, lecturer at the Major Seminary in Radom; he specializes in the theology of communication and communion; address for correspondence-e-mail address: ksemjot@tlen.pl.

${ }^{1}$ Cf. George WeIGel, Katolicyzm ewangeliczny. Gruntowna reforma Kościoła w XXI wieku, trans. Grażyna Gomola and Aleksander Gomola (Cracow: Wydawnictwo M, 2014). "The term «evangelical Catholicism» refers to a new type of the Catholic religion, emerging nowadays as a result of major changes regarding the ways of proclaiming the Gospel, interpreting morality, and understanding the nature of the Church. Weigel emphasizes that the new version of Catholicism should constitute an effective response to various kinds of challenges recently faced by global Christianity, which has been struggling with many social and ideological trends transforming cul- 
Ignacy Bokwa published an extensive study on the situation of theology in modernity (modernism) and postmodernity (postmodernism) ${ }^{2}$ and today debates already concern transmodernity (transmodernism).

\section{THE FIASCO OF THE THEORY OF SECULARIZATION}

Above all, we have witnessed the collapse of the theory of secularization, which dominated the Western world's thinking about religion in the $20^{\text {th }}$ century and predicted that modernization processes as well as the development of science and technology inevitably led to the emergence of atheistic or religiously indifferent societies. There has been an increased interest in various forms of religion and an increase in the significance of religious issues in the public sphere. Its specificity lies not so much in a rejection of religion or in questioning its rationality as in a return of various religious phenomena in a new form. Rather than the twilight of religion, what is spoken of is a change in its basic functions in social life, and the contemporary metamorphoses of Catholicism are an element of a global process that concerns new forms of interpreting and experiencing religion. ${ }^{3}$

\section{THE CULTURE OF TRANSMODERNITY}

The form of secularization and desecularization processes depends to a great extent on the general cultural climate in which the postmodernist mentality is replaced by the culture of transmodernity. Jacques Derrida, Richard Rorty, or Gianni Vattimo proclaimed the imminent twilight of the unchanging foundation of culture and stable moral beliefs, the praise of temporariness, mutability, and transience, the elimination of objective truth, and a profound reinterpretation of morality, religion, and culture. ${ }^{4}$

ture, morality, and people's mentality on a global scale" (Andrzej KoBYLIŃSKI, "Hermeneutyka nieciągłości i pentekostalizacja. Współczesne metamorfozy religii chrześcijańskiej," Teologia i Moralność 11 (2016), no. 2 (20): 245.

${ }^{2}$ Ignacy BoKWA, Teologia $w$ warunkach nowoczesności i ponowoczesności (Sandomierz: Wydawnictwo Diecezjalne i Drukarnia, 2010). Cf. Krzysztof GóźDź, Janusz CHYŁA, and Sławomir Kunk (ed.), Teologia wobec nurtu ponowoczesności (Pelplin: Wydawnictwo „Bernardinum,” 2012).

${ }^{3}$ Cf. KobYLIŃSKI, "Hermeneutyka nieciągłości i pentekostalizacja," $245 \mathrm{ff}$.

${ }^{4}$ Cf. ibid., 246ff. 
Recently there has been talk about the twilight of postmodernism and about the birth of the transmodernist view of the world and the human being. The adjective "transmodernist" means, among other things, dynamically designing and describing social structures; it places emphasis on communication, information, and sustainable development. Transmodernism has been developing mainly in the southern hemisphere, but it also has a global dimension in the domains of religion, culture, and social life. One of its main representatives is the Argentinian-Mexican philosopher Enrique Dussel, ${ }^{5}$ also regarded as one of the founders of liberation philosophy, directly related to the Latin American liberation theology. In the works of Jürgen Habermas and Mikhail Epstein the concept of transmodernism mainly serves the purpose of apprehending the key elements of the identity of our epoch after the twilight of postmodernism. ${ }^{6}$

The transmodernist conception challenges the tradition of the modern era and calls for overcoming the postmodernist legacy; it rejects Eurocentrism, Occidentalism, and the dominance of rational thinking in Greek philosophy; it places strong emphasis on the role of spirituality, alternative religions, and transpersonal psychology; it rejects secularization theories as well as enhances the significance of religions and worldviews; it promotes an ecological and globalist approach, while at the same time drawing attention to threats posed by technology; it combines numerous elements from various worldview conceptions, highlights the significance of spirituality, religion, and some esoteric contents as well as certain aspects of Marxist philosophy and Catholic liberation theology. Transmodernism is sometimes presented as a universal and integral theory, creating a great synthesis of what is premodern, modern, and postmodern. ${ }^{7}$ One of the authors accurately diagnosing the phenomenon of transmodernism is the Belgian philosopher and theologian Marc Luyckx Ghisi. ${ }^{8}$

\footnotetext{
${ }^{5}$ Cf. Mohammad H. TAmdgidi, George Ciccariello-Maher and Ramón Grosfoguel, Conversations with Enrique Dussel. For a bibliography of this thinker's works, see: https://en.wikipedia. org/wiki/Enrique_Dussel.

${ }^{6}$ Cf. KoBYLIŃSKi, "Hermeneutyka nieciągłości i pentekostalizacja," $246 \mathrm{ff}$.

${ }^{7}$ Cf. ibid., 248.

${ }^{8}$ Marc Luyckx GHISI, "Towards a Transmodern Transformation of our Global Society: European Challenges and Opportunities,” Journal of Futures Studies 15, no. 1 (2010): 39-48.
} 


\section{PROBLEMS WITH THE HERMENEUTICS OF DISCONTINUITY}

Global processes meet the reform initiated in the Catholic Church after the Second Vatican Council. Benedict XVI stated that huge problems with the reception of Vatican II were caused by the clash of two contrary ways of interpreting and implementing conciliar documents: the hermeneutics of reform and continuity and the hermeneutics of discontinuity and rupture. This erroneous interpretation of Vatican II resulted in confusion and led to deep religious crisis as well as to rupture with tradition-to a split into the preconciliar Church and the post-conciliar Church. Advocates of the hermeneutics of discontinuity consider the Council's documents as an outcome of compromises preserving many outdated and already useless elements. In numerous Catholic circles the hermeneutics of discontinuity or rupture prevailed, often gaining support in the mass media and in part of contemporary theology. It may seem convincing because it emphasizes that the documents of Vatican II opened the Church to the world and started a new era in the history of Christianity. In reality, it is more accurate to say that they redefined the relations of the Church and its faith to man and the contemporary world. ${ }^{9}$

General councils were convened mainly in the face of danger threatening the Church's faith, though the so-called ecumenical councils were also meant to define ecclesiastical discipline and to sanction major political agreements. ${ }^{10}$ In the case of the last council, the need addressed was different: dialogue with the world. ${ }^{11}$ Its documents are statements of the universal

\footnotetext{
${ }^{9}$ Cf. Joseph RATZINGER, Raport o stanie wiary-z kard. Josephem Ratzingerem rozmawia Vittorio Messori, trans. Zyta Orszyn, Jan Chrapek, et al. (Cracow: Michalineum, 1986), 23-37; Joseph RatZinger, Sól ziemi. Chrześcijaństwo i Kościót katolicki na przełomie tysiącleci-z kard. Josephem Ratzingerem rozmawia Peter Seewald, trans. Grzegorz Sowiñski (Cracow: Znak, 1997), 105-184; BENEDICT XVI, "Wydarzenia, które zachowamy w pamięci i sercu," L'Osservatore Romano (Polish edition) 27, no. 2 (2006): 15-20; KoBYLIŃSKI, Hermeneutyka nieciagłości i pentekostalizacja, 249ff.

${ }^{10}$ Cf. Janusz DYL, Sobory powszechne w drugim tysiącleciu chrześcijaństwa (Tarnów: Biblos, 1997), 9.

${ }^{11}$ Cf. ibid., 144-165; Marek SKIERKOwSKI, Powotanie i warsztat teologa. Wprowadzenie do teologii (Tarnów: Biblos, 2012), 101-114. However, Rev. Ignacy Bokwa makes a significant comment in Breviarium fidei. Wybór doktrynalnych wypowiedzi Kościoła (Poznań: Św. Wojciech, 2007), of which he was editor: "It was not the council's intention to define new articles of faith, but the reading of its documents unambiguously leads to the conclusion that many of them have a dogmatic character" (p. 449, "Zamiarem soboru nie było definiowanie nowych prawd wiary, lecz lektura jego dokumentów prowadzi jednoznacznie do wniosku, że wiele $\mathrm{z}$ nich ma charakter dogmatyczny").
} 
Church, whose fundamental constitution derives from God, ${ }^{12}$ and for this reason they must be treated properly ${ }^{13}$; what remains the main issue is, of course, the appropriate hermeneutics of the Church's teaching. ${ }^{14}$ This problem is not solved by the thesis about the graded binding force of the council's documents, because what is also important is the interrelatedness of their contents. ${ }^{15}$ The best path in this case is to patiently read these documents in order to discern where reception has been narrowed and to find landmarks for the contemporary ecclesiastical identity. ${ }^{16}$

The conciliar picture of the Church combines the significant contents of biblical words about the Church with the large body of tradition (especially patristic), consciously blowing apart the post-Tridentine apologetic reductions, ${ }^{17}$ taking into account the spiritual and theological achievements of the previous century, and trying to develop a credible picture of the Church. The 1985 Extraordinary Synod of Bishops made everyone aware that the reception of the Council's teaching was a constant and urgent task and brought to the fore the understanding of the Church as communion. As certain conciliar accents have been ignored or repressed, the systematic development of new guidelines for the understanding of the Church becomes particularly important. ${ }^{18}$ This is not easy, because the Council did not leave a uniform, system-

\footnotetext{
${ }^{12}$ Cf. Jan-Heiner TÜCK, "Erinnerung auf die Zukunft. 50 Jahre Zweites Vatikanisches Konzil," in Erinnerung auf die Zukunft. Das Zweite Vatikanische Konzil, ed. Jan-Heiner TücK (Freiburg-Basel-Wien: Herder, 2012), 21ff.

${ }^{13}$ Cf. Otto H. PESCH, Das Zweite Vatikanische Konzil. Vorgeschichte-Verlauf_ErgebnisseWirkungsgeschichte (Kevelaer: Matthias-Grünewald 2011 ${ }^{3}$ ), 359-361.

${ }^{14}$ BenEDICT XVI, "Apostolic Letter in the form of «motu proprio» Porta Fidei" (2012), no. 5: "I would also like to emphasize strongly what I had occasion to say concerning the Council a few months after my election as Successor of Peter: 'if we interpret and implement it guided by a right hermeneutic, it can be and can become increasingly powerful for the ever necessary renewal of the Church."” Cf. Jan-Heiner TüCK, "Die Verbindlichkeit des Konzils. Die Hermeneutik der Reform als Interpretationschlüssel," in Erinnerung auf die Zukunft, 85-90.

${ }^{15}$ Cf. TüCK, "Die Verbindlichkeit des Konzils," 91-96.

${ }^{16}$ Cf. TÜCK, "Erinnerung auf die Zukunft. 50 Jahre Zweites Vatikanisches Konzil," 19-21; TÜCK, "Die Verbindlichkeit des Konzils," 97-103; Rainer BuCHER, "Nur ein Pastoralkonzil? Zum Eigenwert des Zweiten Vatikanischen Konzils," Herder Korrespondenz Spezial 2 (2012): 9-13; Marek JAGODZIŃSKI, "Sobór Watykański II w perspektywie teologiczno-eklezjalnej," in Studia soborowe. Historia i nauczanie Vaticanum II, ed. Michał Białkowski (Toruń: Oficyna Wydawnicza Finna, 2013), 322ff.

${ }^{17}$ See: Wolfgang Beinert, "Ein Grundsatzkonflikt. Das Konzil und die Piusbrüder," Herder Korrespondenz Spezial 2 (2012): 19-22.

${ }^{18}$ Cf. Medard KeHL, Die Kirche. Eine katholische Ekklesiologie (Würzburg: Echter 1994³), 48ff; Hans SCHELKSHORN, "Das Zweite Vatikanische Konzil als kirchlicher Diskurs über die Moderne. Ein Philosophischer Beitrag zur Frage nach der Hermeneutik des Konzils," in Erinnerung auf
} 
atic picture of the Church: referring to tradition and discerning demands for renewal, it rather tried to reconcile the assumptions of hierarchical-jurisdictional ecclesiology (the Church as societas perfecta) with the earlier community- and spirituality-oriented tradition (the Church as personal mysterium and social communio) - an approach that turned out not to be particularly satisfactory. ${ }^{19}$ The juxtaposed and sometimes contradictory statements were supposed to give rise to the foundation of the ecclesiology approved by the Church - not to a system, ${ }^{20}$ whose development was left to theology, and theology is still only beginning this task today. ${ }^{21}$

\section{PROTESTANTIZATION AND PENTECOSTALIZATION OF CHRISTIANITY?}

The problem of Protestantization of the Catholic Church ${ }^{22}$ appeared, among other occasions, in the context of the Extraordinary Synod of Bishops in the autumn of 2014, and the Protestantization of the view of priesthood was an issue often raised by Cardinal Gerhard Müller, former Prefect of the Congregation for the Doctrine of the Faith. The secularization and desecularization of religion as well as the Protestantization of Catholicism are linked nowadays to the global process of the Pentecostalization of Christianity. It means an immensely quick growth in the size of Pentecostal communities

\footnotetext{
die Zukunft, 54-84. An interesting review of the rules of interpreting the Council's teaching was provided by Otto H. PESCH (Das Zweite Vatikanische Konzil, 148-160).

${ }^{19}$ Otto H. Pesch presented examples of ambivalent results yielded by these efforts in the book cited below, Das Zweite Vatikanische Konzil (p. 357).

${ }^{20}$ Cf. Walter KASPER, "Die Kirche als Mysterium - Was glaubt die Kirche von sich selbst," in KASPER, Die Kirche Jesu Christi. Schriften zur Ekklesiologie I (Freiburg-Basel-Wien: Herder, 2008), 261-280; Pesch, Das Zweite Vatikanische Konzil, 161-206; Christoph Theobald, "Die Kirchenkonstitution Lumen gentium. Programmatische Vision-Kompromisstext-Ansatz für einen Paradigmenwechsel," in Erinnerung auf die Zukunft, 210-214.

${ }^{21}$ Cf. Walter KASPER, "Die bleibende Herausforderung durch das II. Vatikanische Konzil. Zur Hermeneutik der Konzilaussagen," in KASPER, Die Kirche Jesu Christi. Schriften zur Ekklesiologie I, 295ff; JAGODZIŃSKI, “Sobór Watykański II w perspektywie teologiczno-eklezjalnej," 325, n. 18. John Paul II referred to the new Code of Canon Law as "the last document of the Council." Apostolic Constitution Sacri Canones (1990), Acta Apostolicae Sedes 82 (1990): 1038. See. Sabine Demel, "Wer interpretiert wen? Der Codex Iuris Canonici als „Krönung” des Konzils,” Herder Korrespondenz Spezial 2 (2012): 13-18.

${ }^{22}$ See: Sławomir PŁusA, "Pentekostalizm czy odnowa charyzmatyczna Kościoła?," in Kwestie dyskutowane w teologii dzisiaj, ed. Marek Jagodziński (Radom: Wydawnictwo Diecezji Radomskiej AVE, 2017), 273-294.
} 
and the gradual transformation of numerous Churches and religious organizations into a universal variety of global charismatic Christianity. This is often referred to as the "charismaticization" of the Christian religion or the birth of Pentecostal or evangelical Christianity, and the process of deep transformation at the level of doctrine or religious life practices is taking place also within traditional Christian churches. ${ }^{23}$

Pentecostal Christianity is a highly public religion. It refuses to accept a marginal and only private role; it publicly expresses its religious beliefs; it engages in social and political affairs, transforming the public and political sphere through a dualistic religious epistemology, according to which the world is the arena of struggle between God and Satan. In many countries there is even talk about a Pentecostal electorate. An extremely interesting aspect of the global process of Pentecostalization of Christianity is the Pentecostalization of what is known as Christian Zionism. ${ }^{24}$

Some strongly criticize the thesis about the Protestantization or Pentecostalization of the Catholic Church. ${ }^{25}$ They argue that the very fact of that charismatic or Pentecostal communities are developing dynamically does not prove that there is an intention to create a universal version of Christianity. The development of these communities stems, above all, from the desire to reach out to people with the offer of salvation. Thus, the measure of Church renewal is openness to the work of the Holy Spirit building unity in the Church and stimulating its missional character. Equating the charismatic dimension of Christian communities with the Pentecostal movement is also a serious mistake and a misunderstanding of the place of charisms in the Catholic Church. Letter Iuvenescit Ecclesia (2016) by the Congregation for the Doctrine of the Faith, no. 12, reads: "The hierarchical and charismatic gifts, therefore, appear united in reference to the intrinsic relationship between Jesus Christ and the Holy Spirit. The Paraclete is, contemporaneously, the one who distributes efficaciously, through the sacraments, the salvific grace offered by Christ dead and risen again, and He is the one who bestows the charisms. ${ }^{26}$ One cannot therefore fail to see the difference between the

\footnotetext{
${ }^{23}$ Cf. KoBYLIŃSKi, "Hermeneutyka nieciągłości i pentekostalizacja," 250-252.

${ }^{24}$ Cf. ibid., $252 \mathrm{ff}$.

${ }^{25}$ Cf. Leszek MisiarczyK, “Czy Kościołowi katolickiemu grozi rzeczywiście pentekostalizacja?", http://www.fronda.pl/a/ks-prof-leszek-misiarczyk-dla-frondapl-czy-kosciolowi-katolickiemuw-polsce-rzeczywiscie-grozi-pentekostalizacja,55502.html (accessed: 27.11.2017).

${ }^{26}$ Congregation for the Doctrine of the Faith, "Letter Iuvenescit Ecclesia to the Bishops of the Catholic Church Regarding the Relationship Between Hierarchical and Charismatic Gifts in the Life
} 
Pentecostal movement and Catholic charismatic renewal. ${ }^{27}$ Moreover, individuals associated with the Catholic charismatic movement not only refuse to leave and join the Pentecostalists but actually deepen their relationship with the Catholic Church (few exceptions do happen, of course). Some resume practicing the Catholic faith. Many candidates for priesthood and monastic life come from charismatic movements. ${ }^{28}$

In 1992, John Paul II addressed the International Catholic Charismatic Renewal Office as follows: "I willingly join you in giving praise to God for the many fruits which it has borne in the life of the Church. The emergence of the Renewal following the Second Vatican Council was a particular gift of the Holy Spirit to the Church. It was a sign of a desire on the part of many Catholics to live more fully their Baptismal dignity and vocation as adopted sons and daughters of the Father, to know the redeeming power of Christ our Saviour in a more intense experience of individual and group prayer, and to follow the teaching of the Scriptures by reading them in the light of the same Spirit who inspired their writing. Certainly one of the most important results of this spiritual reawakening has been that increased thirst for holiness which is seen in the lives of individuals and in the whole Church." 29

There is, however, a need for pastoral vigilance in order not to stop at the charismatic manifestations of the Holy Spirit's work in isolation from personal conversion and sacramental life. Another extreme attitude emerged, too - a fear of kerygmatic proclamation, to the extent that a lack of reference to the sacraments is also classified as a symptom of the Protestantization of the Church. Some fail to notice that first it is necessary to build a personal relationship with Christ and then to show the forms of His presence in the Church. Kerygma is, therefore, not Protestant but apostolic in nature, which Pope Francis firmly asserted in his exhortation Evangelii Gaudium, nos. 164ff. ${ }^{30}$

\footnotetext{
and the Mission of the Church," no. 12. http://www.vatican.va/romancuria/congregations/cfaith /documents/rc_con_cfaith_doc_20160516_iuvenescit-ecclesia_en.html (accessed: 1.11.2017).

${ }^{27}$ Cf. MisiarCzyK, “Czy Kościołowi katolickiemu grozi rzeczywiście pentekostalizacja?"

${ }^{28} \mathrm{Cf}$. ibid.

${ }^{29}$ Pope John PAul II, “Address of His Holiness John Paul II to the Council of the International Catholic Charismatic Renewal Office," no. 1, https://w2.vatican.va/content/john-paul-ii/en/ speeches / 1992/march/documents/hf_jp-ii_spe_19920314_charismatic-renewal.html (accessed: 1.11.2017).

${ }^{30}$ Cf. PŁusA, "Pentekostalizm czy odnowa charyzmatyczna Kościoła?," 289-293.
} 


\section{EMOTIONALITY IN RELIGION}

The essence of religious experience is more and more often restricted to the emotional domain nowadays. This process started in Christianity 500 years ago, when the Reformation questioned the sacramental order, which led to a focus on subjective religious experience. In the $17^{\text {th }}$ century, John Wesley, the founder of Methodism, introduced the practice of sharing the experience of faith during prayer meetings. The American offshoot of this sect is Pentecostalism, placing an even greater emphasis on the emotional dimension of religious experience as the basic criterion of the authenticity of the Holy Spirit's activity. In many Pentecostalist communities superficial emotionalism is present, which can lead to the trivialization of religious experience; sometimes it may even upset the mental and emotional balance of the members of religious communities and result in abuse. In the Catholic religiosity, the believer should direct faith towards the person of Jesus Christ rather than talk about his or her own experiences, struggles, or speculations. In liturgy and observances there is a place for emotional flavour, but this place is not central and does not become the main criterion of genuineness. Faith is located in the intellect and partly in will rather than in feelings, even if it is sometimes reflected in the sensory sphere. ${ }^{31}$

\section{DISINTEGRATION OF CHRISTIANS}

In 1900 , there were 1600 churches, religious organizations, and sects in the world. By 2000 this number increased to 34000 , by 2012 - to 43000 , by 2016 an increase to the level of 45000 could be expected, and by 2025 there will probably be as many as 55000 denominations. This leads to increasingly great fragmentation, decomposition, and Pentecostalization. The development of Pentecostal communities is highly rapid. In Africa or South America Catholic parishes frequently fail to withstand "competition" and adopt very effective Pentecostalist methods of evangelization. Pentecostalism originated in the United States in 1901. The current number of Pentecostals is estimated at 600 to 800 million, and it will have reached a billion by 2025. In terms of actually practicing religion they already are the largest Christian denomination. ${ }^{32}$

\footnotetext{
${ }^{31}$ Cf. KobYLIŃSKi, "Hermeneutyka nieciągłości i pentekostalizacja," $253 \mathrm{ff}$.

${ }^{32}$ Cf. ibid., 255.
} 
International Bulletin of Mission Research ${ }^{33}$ reports that in 2014 the number of Christians in Latin America was larger than the Christian population in Europe, although 100 years ago there were still six times more Christians in Europe than in Latin America. In 2025, the number of Christians will be the highest in Africa-up to 700 million. By 2050, Asia will have outdone Europe in terms of the number of Christians of all denominations. In 2050, $80 \%$ of all Christians will live in Asia, Africa, and Latin America, whereas in 1900 this group accounted for only $20 \%$ of the world's Christian population. In 2025, the largest number of Christians (200 million) will live in China, and studies show that in 2030 there will be as many Christians there as 250 million, the vast majority of them being Pentecostals, whose teaching about success in life and wealth as a sign of God's blessing perfectly corresponds with the contemporary mentality of Chinese society. ${ }^{34}$

There is, of course, a serious methodological problem involved in demographic and sociological studies of religion. What criteria of confessional identity should be regarded as decisive? How to classify people who frequently change their confessional affiliation? How to treat Christians who do not want to belong to any denomination and create their own syncretic vision of the Christian religion? How to define and count Pentecostal Christians, constituting a huge galaxy of diverse movements and communities? The usual practice is to divide them into three categories. The first category comprises members of classic Pentecostal denominations, founded worldwide since 1901. The second one is charismatics from traditional Churches. Those classified into the third category are referred to as independent charismatics, who severed their relations with confessional or denominational Pentecostalism. The classification and chronology of the first two types is simple, but there are thousands of associations that resemble the first two types even though they do not fit into their definition. ${ }^{35}$

\footnotetext{
${ }^{33}$ Cf. Todd M. Johnson, Gina A. Zurlo, Albert W. Hickman, and Peter F. Crossing, "Christianity 2016: Latin America and Projecting Religions to 2050," International Bulletin of Mission Research 40, no. 1 (2016), 22-29.

${ }^{34}$ Cf. KoBYLIŃSKI, "Hermeneutyka nieciągłości i pentekostalizacja," $255 \mathrm{ff}$.

${ }^{35}$ Cf. ibid., 256ff. See: Reinhard HempelmanN, "Evangelikale und Reformation," Herder Korrespondenz Spezial (Nach der Galubensspaltung. Der Zukunft des Christentums) 2 (2016): 21-24.
} 


\section{DECENTRALIZATION OF THE CATHOLIC CHURCH}

Decentralization in the ecclesiastical sense is another name for the synodalization or regionalization of global Catholicism. In his exhortation Evangelii Gaudium, Pope Francis wrote: "It is not advisable for the Pope to take the place of local Bishops in the discernment of every issue which arises in their territory. In this sense, I am conscious of the need to promote a sound "decentralization"" (no. 16). ${ }^{36}$

The internal process of decentralization in the Catholic Church provokes a question: what is Catholicism going to be like in the future? In what way is it going to retain its own identity in the context of global changes? The challenges demand great spiritual and intellectual commitment from Catholics. In Poland, these problems have been exemplified by two decrees of Polish Bishops' Conference, issued in 2015, whose aim is to defend Catholicism against the alien religious influences - this concerns the practice of what is called "wicket confession" as well as the ideas of generational sins and transgenerational forgiveness, incompatible with the Catholic view of the world and the human being. ${ }^{37}$

Religions are undergoing a process of globalization too. What happens is not only the intermingling of elements of various cultures and religions but also division and fragmentation within organizational structures. In many countries, the risk of the acceptance of the hermeneutics of discontinuity and rupture is perhaps even more valid today than it was after the Council. It should therefore be stressed that the defence of its own doctrinal identity has a decisive influence today on the condition of the Catholic Church in the nearest decades.

One universal version of Catholicism for the whole world seems to be impossible today. Due to the process of decentralization, Catholics have to adapt to a completely new historical situation, and it is hard to predict what the process of profound changes will lead to. It is enough to mention the clash

\footnotetext{
${ }^{36}$ Pope FrANCIS, Evangeliii Gaudium, http://w2.vatican.va/content/francesco/en/apost_exhortations /documents/papa-francesco_esortazione-ap_20131124_evangelii-gaudium.html (accessed: 20.01.2018). Cf. KoBYLIŃSKI, "Hermeneutyka nieciągłości i pentekostalizacja,” 257.

${ }^{37}$ Cf. ibid. See: Marek JAGODZIŃSKI, “Czy istnieje kwestia „,przebaczenia międzypokoleniowego?,” Roczniki Teologiczne 63, no. 2 (2016): 155-169; Marek JAGODZIŃSKI, “'Zwyczajne’ działanie Boga w sakramentach w kontekście kontrowersyjnych koncepcji teologiczno-pastoralnych," Studia Teologii Dogmatycznej (Nadzwyczajne i nadprzyrodzone) 2 (2017): 49-64; Sławomir PŁuSA, "Między grzechem a zranieniem. Wokół 'uzdrowienia międzypokoleniowego'," in Kwestie dyskutowane w teologii dzisiaj, ed. Marek Jagodziński, 71-92.
} 
between divergent interpretations of exhortation Amoris Laetitia, which exemplifies the new stage in the history of the Catholic Church. ${ }^{38}$

Andrzej Kobyliński suggests that it might be worth returning to Pope Paul VI's mysterious words: "Inside Catholicism itself, a non-Catholic way of thinking seems sometimes to have taken the upper hand, and it is possible that this same non-Catholic thinking will in tomorrow's world be the stronger one within Catholicism itself. But this new non-Catholic thought will never represent the thought of the Catholic Church. A small flock must survive, even though it be very tiny flock." Today it is still difficult to apprehend the deepest meaning of these dramatic words because we still do not clearly see the contours of the world that is coming, but these words should be taken into account when assessing the future fate of Catholicism and Christianity. ${ }^{39}$

It must be added that, since the beginning of Pope Francis' pontificate, his decentralization initiatives have stirred anxiety. ${ }^{40}$ This anxiety is largely understandable, but it is also fuelled by circles resistant to his intended moves, as well as by the superficial reception of media contents, painting facile, simplified, excessively contrastive and polarized picture of reality. What lies at the root of the problem is the controversy, which Medard Kehl had much earlier referred to as "the dispute of cardinals" (Joseph Ratzinger and Walter Kasper), about the relationship between the universal Church and local Churches. The Congregation for the Doctrine of the Faith published declaration Dominus Iesus (2000), in which it stated that the relationship be-

\footnotetext{
${ }^{38}$ Cf. KobYLIŃSKI, "Hermeneutyka nieciągłości i pentekostalizacja," 258. See: Jarosław WoJTKUN, "Sytuacja osób rozwiedzionych, żyjących w związkach cywilnych, wobec sakramentów. Przegląd komentarzy na temat ósmego rozdziału Amoris laetitia", in Kwestie dyskutowane w teologii dzisiaj, ed. Marek Jagodziński, 31-52; Magnus STRIET, "Wunderbar, man streitet sich," Herder Korrespondenz 2 (2017): 13-15.

${ }^{39}$ Cited in: KobYLIŃsKI, "Hermeneutyka nieciągłości i pentekostalizacja," 259. English text cited from: http://www.sspxasia.com/Documents/SiSiNoNo/1994_October/They_Think_Theyve_ Won_PartVIII.htm (accessed: 20.04.2018).

${ }^{40}$ This is well shown by a review of articles published, e.g., in Herder Korrespondenz: Ulrich RuH, "Der Papst und die Christenheit," Herder Korrespondenz 11 (2013): 541-543; Ralph RotTE, "Noch ein weiter Weg. Neue Transparenz und Reformanstrengungen bei den Vatikanfinanzen," Herder Korrespondenz 2 (2014): 65-70; S.O., "Bischofssynode: Ergebnisse der Umfrage veröffentlicht," Herder Korrespondenz 3 (2014): 115-117; U.R., "Ergänzung," Herder Korrespondenz 9 (2014): 437ff; Klaus LüDICKE, "Evolution oder Revolution?” Herder Korrespondenz 10 (2015): 509-512; Andreas WollBOLD, "Ermutigung zur Seelsorge," Herder Korrespondenz 6 (2016): 13ff.; Rainer BuCHER, "Mehr als Stellschrauben," Herder Korrespondenz 6 (2016): 15ff; Thomas, SchüLLER, "Freiheit für das Volk—Strenge für den Klerus," Herder Korrespondenz 8 (2016): 22 25; STRIET, "Wunderbar, man streitet sich," 13-15.
} 
tween the universal Church and local Churches is one of mutual interiority (mutua interioritas), "simultaneous priority," and so they cannot be derived from one another or reduced to one another in matters of their foundation and continuance. After stressing that the universal Church is not an "outcome" of the communion of local Churches, the document stated that the universal Church was a reality ontologically and temporally prior to particular Churches. Walter Kasper, by contrast, stressed that, from the beginning, one Church existed "in and from" local Churches and that it could not be equated with the Roman Church. The controversy continued, with the issue of prerogatives in its background: the Eastern Churches understand the Church as a communion of local Churches, while the Western Church adopted a centralist attitude. ${ }^{41}$ Pope Francis decentralization efforts are therefore inspired by the communion-oriented enhancement of local Churches, advocated by Walter Kasper.

Another very interesting issue is the spiritual background of the South American pope, whose choice of papal name, new style, initiatives, and proven credibility have made him famous worldwide, but the media interest, his dramatic life story, and his manner easily obscure his spiritual profile. He has published few texts, and his views are known thanks to pastoral activity rather than writings. ${ }^{42}$ It has been spitefully remarked than he is a representative of a "Copacabana theology," but this expression has come to refer to a theology that is comprehensible and pastorally oriented. Apart from the Bible, the pope's spiritual background includes the works of Argentinian, European, and ancient authors, theological and spiritual writings by St Augustine, St Ignatius Loyola, Pierre Favre, Henri de Lubac and Michel de Certeau, ${ }^{43}$ St John of the Cross and St Thérèse of Lisieux, as well as St Thomas Aquinas, St Vincent of Lérins, St Dorotheus of Gaza, and more recent authors, such as Romano Guardini, Rainer Maria Rilke, Hugo Rahner, Hans Urs von Balthasar, and Lucio Gera. ${ }^{44}$ This should be remembered when we encounter spiteful or upsetting comments and nightmare scenarios of the future.

\footnotetext{
${ }^{41}$ Cf. Medard KeHL, "Der Disput der Kardinäle. Zum Verhältnis von Universalkirche und Ortskirchen," Stimmen der Zeit 4 (20003): 219-232.

${ }^{42}$ See: Michael Sievernich, "Das theologische Prinzip von Papst Franziskus / Pater Jorge Mario Bergoglio SJ," Theologisch-praktische Quartalschrift 1 (2015): 20-29.

${ }^{43}$ See: Daniel Bogner, "Prägender Einfluss," Herder Korrespondenz 10 (2017): 21-24.

${ }^{44}$ See: Michael SieVERnich, “Die Bibliothek des Papstes," Herder Korrespondenz 5 (2016): 30-33.
} 


\section{BIBLIOGRAPHY}

BeINERT, Wolfgang. "Ein Grundsatzkonflikt. Das Konzil und die Piusbrüder" Herder Korrespondenz Spezial 2 (2012): 19-22.

BoGNER, Daniel. "Prägender Einfluss.” Herder Korrespondenz 10 (2017): 21-24.

BoKwA, Ignacy, ed. Breviarium fidei. Wybór doktrynalnych wypowiedzi Kościoła [Breviarium fidei. A selection of doctrinal statements of the Church]. Poznań: Św. Wojciech, 2007.

BoKwA, Ignacy. Teologia $w$ warunkach nowoczesności i ponowoczesności [Theology in the conditions of modernity and postmodernity]. Sandomierz, Poland: Wydawnictwo Diecezjalne i Drukarnia w Sandomierzu, 2010.

BuCHER, Rainer. "Mehr als Stellschrauben.” Herder Korrespondenz 6 (2016): 15ff.

Bucher, Rainer. "Nur ein Pastoralkonzil? Zum Eigenwert des Zweiten Vatikanischen Konzils." Herder Korrespondenz Spezial 2 (2012): 9-13.

CONGREGATION FOR THE DoctRine Of THE FAITH. "Declaration Dominus Iesus" (2000)

CONGREGATION FOR THE DOCTRINE OF THE FAITH. "Letter Iuvenescit Ecclesia" (2016).

DemEL, Sabine. "Wer interpretiert wen? Der Codex Iuris Canonici als 'Krönung' des Konzils." Herder Korrespondenz Spezial 2 (2012): 13-18.

DYL, Janusz. Sobory powszechne $w$ drugim tysiącleciu chrzeœcijañstwa [Ecumenical councils in the second millennium of Christianity]. Tarnów, Poland: Biblos, 1997.

GHISI, Marc Luyckx. "Towards a Transmodern Transformation of our Global Society: European Challenges and Opportunities." Journal of Futures Studies 15, no. 1 (2010): 39-48.

GóźDź, Krzysztof, Janusz ChYŁA, and Sławomir KunKA, eds. Teologia wobec nurtu ponowoczesnoæci [Theology versus the current of postmodernity]. Pelplin: Wydawnictwo „Bernardinum,” 2012.

Hempelmann, Reinhard. "Evangelikale und Reformation." Herder Korrespondenz Spezia” (Nach der Galubensspaltung. Der Zukunft des Christentums) 2 (2016): 21-24.

JAGODZIŃSKI, Marek. “'Zwyczajne' działanie Boga w sakramentach w kontekście kontrowersyjnych koncepcji teologiczno-pastoralnych" [God's "ordinary" activity in the sacraments in the context of controversial theological and pastoral ideas]. Studia Teologii Dogmatycznej 2 (2017): 49-64.

JAGODZIŃSKI, Marek. "Czy istnieje kwestia 'przebaczenia międzypokoleniowego'?” [Is there an issue of 'transgenerational forgiveness'?] Roczniki Teologiczne 63, no. 2 (2016): 155-169.

JAGODZIŃSKI, Marek. “Sobór Watykañski II w perspektywie teologiczno-eklezjalnej” [A theological and ecclesial perspective on the Second Vatican Council]. In Studia soborowe. Historia $i$ nauczanie Vaticanum II [Conciliar studies: The history and teaching of Vatican II], edited by Michał Białkowski, 321-347. Toruń, Poland: Oficyna Wydawnicza FINNA, 2013.

Johnson, Todd M., Gina A. Zurlo, Albert W. Hickman, and Peter F. Crossing. "Christianity 2016: Latin America and Projecting Religions to 2050." International Bulletin of Mission Research 40, no 1 (2016): 22-29.

KASPER, Walter. "Die bleibende Herausforderung durch das II. Vatikanische Konzil. Zur Hermeneutik der Konzilaussagen.” In Walter KASPER, Die Kirche Jesu Christi. Schriften zur Ekklesiologie I, 200-211. Freiburg-Basel-Wien: Herder, 2008. 
KASPER, Walter. "Die Kirche als Mysterium-Was glaubt die Kirche von sich selbst." In Walter KASPER, Die Kirche Jesu Christi. Schriften zur Ekklesiologie I, 261-280. Freiburg-Basel-Wien: Herder, 2008.

KeHL, Medard. "Der Disput der Kardinäle. Zum Verhältnis von Universalkirche und Ortskirchen.” Stimmen der Zeit 4 (2003): 219-232.

KeHL, Medard. Die Kirche. Eine katholische Ekklesiologie. Würzburg: Echter, 1994³.

KoBYLIŃSKI, Andrzej. "Hermeneutyka nieciągłości i pentekostalizacja. Współczesne metamorfozy religii chrzeœcijańskiej" [The Hermeneutics of discontinuity and Pentecostalization: Contemporary metamorphoses of the Christian religion]. Teologia i Moralność 11 (2016) no. 2 (20): 246-261.

LÜDICKE, Klaus. “Evolution oder Revolution?” Herder Korrespondenz 10 (2015): 509-512.

MisiarCZYK, Leszek. “Czy Kościołowi katolickiemu grozi rzeczywiście pentekostalizacja?” [Is the Catholic Church in Poland really in danger of Pentecostalization?], http://www.fronda.pl/a/ksprof-leszek-misiarczyk-dla-frondapl-czy-kosciolowi-katolickiemu-w-polsce-rzeczywiscie-grozipentekostalizacja,55502.html (accessed: 27.11.2016).

Pesch, Otto H. Das Zweite Vatikanische Konzil. Vorgeschichte-Verlauf-Ergebnisse-Wirkungsgeschichte. Kevelaer: Matthias-Grünewald, $2011^{3}$.

PŁusA, Sławomir. "Między grzechem a zranieniem. Wokół 'uzdrowienia międzypokoleniowego'” [Between sin and injury: Concerning "transgenerational healing"]. In Kwestie dyskutowane w teologii dzisiaj [Issues discussed in theology today], edited by Marek Jagodziński, 71-92. Radom, Poland: Wydawnictwo Diecezji Radomskiej AVE, 2017.

PŁusA, Sławomir. "Pentekostalizm czy odnowa charyzmatyczna Kościoła?" [Pentecostalism or charismatic renewal of the Church?]. In Kwestie dyskutowane $w$ teologii dzisiaj [Issues discussed in theology today], edited by Marek Jagodziński, 273-294. Radom, Poland: Wydawnictwo Diecezji Radomskiej AVE, 2017.

Pope Benedict XVI. “Apostolic Letter Porta Fidei” (2012). Accessed 20 January 2018. https://w2. vatican.va/content/benedict-xvi/en/motu_proprio/documents/hf_ben-xvi_motu-proprio_20111011_ porta-fidei.html.

Pope BENEDICT XVI. "Wydarzenia, które zachowamy w pamiêci i sercu" [The events that we shall keep in our memory and in our hearts]. L'Osservatore Romano (Polish edition.) 27, no. 2 (2006): 15-20.

PoPE Francis. "Apostolic Exhortation Evangelii Gaudium”(2013). Accessed 20 January 2018. http://w2.vatican.va/content/francesco/en/apost_exhortations/documents/papa-francesco_esortazio ne-ap_20131124_evangelii-gaudium.html.

Pope Francis. "Exhortation Amoris Laetitia" (2016). Accessed 20 January 2018. http://w2.vatican.

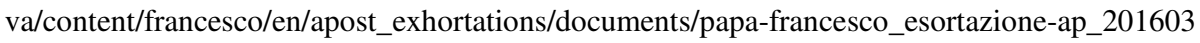
19_amoris-laetitia.html.

Pope John Paul II. “Apostolic Constitution Sacri Canones” (1990).

Pope John Paul II. "Address of His Holiness John Paul II to the Council of the International Catholic Charismatic Renewal Office," no. 1. Accessed 20 January 2018, https://w2.vatican.va/ content/john-paul-ii/en/speeches/1992/march/documents/hf_jp-ii_spe_19920314_charismatic-re newal.html.

RATZINGER, Joseph. Raport o stanie wiary - z kard. Josephem Ratzingerem rozmawia Vittorio Messori [The Ratzinger Report: An Exclusive Interview on the State of the Church]. Interview by Vittorio Messori. Translated by Zyta Orszyn, Jan Chrapek, et al. Cracow: Michalineum, 1986. 
RATZINGER, Joseph. Sól ziemi. Chrześcijaństwo i Kościót katolicki na przełomie tysiącleci-z kard. Josephem Ratzingerem rozmawia Peter Seewald [Salt of the Earth: The Church at the End of the Millennium: An Interview with Peter Seewald]. Translated by G. Sowiński. Cracow: Znak, 1997.

RotTE, Ralph. "Noch ein weiter Weg. Neue Transparenz und Reformanstrengungen bei den Vatikanfinanzen." Herder Korrespondenz 2 (2014): 65-70.

RuH, Ulrich. "Der Papst und die Christenheit." Herder Korrespondenz 11 (2013): 541-543.

S.O. "Bischofssynode: Ergebnisse der Umfrage veröffentlicht." Herder Korrespondenz 3 (2014): $115-117$.

SCHELKSHORN, Hans. "Das Zweite Vatikanische Konzil als kirchlicher Diskurs über die Moderne. Ein Philosophischer Beitrag zur Frage nach der Hermeneutik des Konzils." In Erinnerung auf die Zukunft. Das Zweite Vatikanische Konzil, edited by Jan-Heiner Tück, 54-84. Freiburg-Basel-Wien: Herder, 2012.

SCHÜLLER, Thomas. "Freiheit für das Volk - Strenge für den Klerus." Herder Korrespondenz 8 (2016): 22-25.

Sievernich, Michael. "Das theologische Prinzip von Papst Franziskus / Pater Jorge Mario Bergoglio SJ.” Theologisch-praktische Quartalschrift 1 (2015): 20-29.

SiEvernich, Michael. "Die Bibliothek des Papstes." Herder Korrespondenz 5 (2016): 30-33.

SKIERKowski, Marek. Powo ${ }^{3} a n i e ~ i$ warsztat teologa. Wprowadzenie do teologii [The theologian's vocation and method: An introduction to theology]. Tarnów, Poland: Biblos, 2012.

STRIET, Magnus. “Wunderbar, man streitet sich.” Herder Korrespondenz 2 (2017): 13-15.

TAMDGIDI, Mohammad H., George Ciccariello-Maher, and Ramón Grosfoguel, eds. Conversations with Enrique Dussel on Anti-Cartesian Decoloniality and Pluriversal Transmodernity. Human Architecture Series: Journal of the Sociology of Self-Knowledge 11, no. 1 (2013), Belmont: Ahead Publishing House, 2013.

TheobALD, Christoph. "Die Kirchenkonstitution Lumen gentium. Programmatische Vision-Kompromisstext-Ansatz für einen Paradigmenwechsel." In Erinnerung auf die Zukunft. Das Zweite Vatikanische Konzil, edited by Jan-Heiner Tück, 201-220. Freiburg-Basel-Wien: Herder, 2012.

TüCK, Jan-Heiner. "Die Verbindlichkeit des Konzils. Die Hermeneutik der Reform als Interpretationschlüssel." In Erinnerung auf die Zukunft. Das Zweite Vatikanische Konzil, edited by Jan-Heiner Tück, 85-104. Freiburg-Basel-Wien: Herder, 2012.

TÜCK, Jan-Heiner. "Erinnerung auf die Zukunft. 50 Jahre Zweites Vatikanisches Konzil.” In Erinnerung auf die Zukunft. Das Zweite Vatikanische Konzil, edited by Jan-Heiner Tück, 11-30. Freiburg-Basel-Wien: Herder, 2012.

U.R. "Ergänzung," Herder Korrespondenz 9 (2014): 437ff.

WeIGEL, George. Katolicyzm ewangeliczny. Gruntowna reforma Kościoła w XXI wieku [Evangelical Catholicism: Deep Reform in the 21st-Century Church]. Translated by Grażyna Gomola and Aleksander Gomola. Cracow: Wydawnictwo M, 2014.

WoJTKun, Jarosław. "Sytuacja osób rozwiedzionych, żyjących w związkcha cywilnych, wobec sakramentów. Przegląd komentarzy na temat ósmego rozdziału Amoris laetitia" [The situation of divorced people living in civil marriages, with regard to the sacraments. A review of commentaries on the eighth chapter of Amoris Laetitia]. In Kwestie dyskutowane w teologii dzisiaj [Issues discussed in theology today], edited by Marek Jagodziński, 31-52. Radom, Poland: Wydawnictwo Diecezji Radomskiej AVE, 2017.

WollbolD, Andreas. “Ermutigung zur Seelsorge.” Herder Korrespondenz 6 (2016): 13ff. 


\section{INTERNET SOURCES}

“Enrique Dussel.” Wikipedia. Accessed 20 January 2018. https://en.wikipedia.org/wiki/Enrique Dussel.

CONGREGATION FOR THE DoctRine OF THE FAITH. "Letter Iuvenescit Ecclesia to the Bishops of the Catholic Church Regarding the Relationship Between Hierarchical and Charismatic Gifts in the Life and the Mission of the Church." Accessed 1 November 2016. http://www.vatican.va /roman_curia/congregations/cfaith/documents/rc_con_cfaith_doc_20160516_iuvenescit-ecclesia _en.html.

MisiarczyK, Leszek. “Czy Kościołowi katolickiemu w Polsce rzeczywiście grozi pentekostalizacja?" [Is the Catholic Church in Poland really in danger of Pentecostalization?]. Accessed 2 January 2017. http://www.fronda.pl/a/ks-prof-leszek-misiarczyk-dla-frondapl-czy-kosciolowikatolickiemu-w-polsce-rzeczywiscie-grozi-pentekostalizacja,55502.html.

\section{Translated by Piotr Czyżewski}

The preparation of the English version of Roczniki Teologiczne (Annals of Theology) and its publication in electronic databases was financed under contract no. 836/P-DUN/2018 from the resources of the Minister of Science and Higher Education for the popularization of science. 